\title{
Establishment of Learners' Character Through Learning Traditional Dance in Senior High School
}

\author{
${ }^{\square}$ Etik Riyaningsih, Maryono, Harini \\ Art Education Study Programme of Post Graduate, \\ Universitas Sebelas Maret, Indonesia
}

Received: December 13, 2017. Revised: April 23, 2018. Accepted: June 10, 2018

\begin{abstract}
This research was conducted to describe the character establishment of learners through learning dance in terms of the learning process, exercises and elements of traditional dance. This research was conducted to find and explain the process of learning traditional dance in the development of learners' character establishment. This research data is in the form of information, documents and learning process collected through interview, literature study and observation. Meanwhile, triangulation method is done to test the validity of data from those various sources. The result shows that learning the traditional dance of Bajul Mahambara can enrich the experience of learners and on the other hand train the intellect and sense by understanding the characters of local wisdom contained in traditional dance. Learning traditional dance can give a positive influence in establishing the character of learners which are (1) religiosity; (2) honesty; (3) responsibility and cooperation; (4) tolerance; (5) discipline; (6) creativity.
\end{abstract}

Keywords: Character Establishment; Culture; Traditional Dance; Learning Activities

How to Cite: Riyaningsih, E., Maryono, \& Harini. (2018). Establishment of Learners' Character Through Learning Traditional Dance in Senior High School. Harmonia: Journal of Arts Research And Education, 18(1), 13-27. doi:http://dx.doi. org/10.15294/harmonia.v18i1.12575

\section{INTRODUCTION}

Character is a very important aspect in shaping a superior person. Character education at the institutional level leads to the establishment of a school culture which are the characters underlying behavior, traditions, daily habits, and symbols practiced by all members of school and community. The school that is an educational institution plays an important role in developing the character of learners through cultural approaches in school. Character-based education has several roles which are as educators, instructors, mentors, trainers, advisers, reformers, models and paragons, personal researchers, creativity drivers, sight generators, regular workers, storytellers, actors, emancipators, evaluators (Asmani, 2011).

Dance is one of the cultural results of the art in the form of body movement that describes and convey certain characters. In other words, dance is one form of communication media in society in the form of symbols. Dance as a work of art from a particular community or community which is influenced by the background of society such as culture, education, wisdom and the characters contained in a community / residence. By incorporating the character and local wisdom is expected to encourage in shaping the intelligence and character of learners. Jazuli (2016) states that the bene-

\footnotetext{
Corresponding author: Jl. Ir. Sutami No.36A, Jebres, Kota Surakarta, Jawa Tengah 57126

E-mail: etikriyaningsih24@gmail.com
} 
fits of dance education for students are to cultivate the taste and provide a psychical ground both theoretically and practically to be able to express feelings through the art media.

Research on character-based education has been widely practiced. One relevant study is a study by Winarsih (2004) on the development of character-based education through the classical dance of Yogyakarta in SMK 1 Kasihan, Bantul. The results show that dance learning with ethnographic study approach by understanding the students thinking structure about character education based on the ethnic-educational study, comprehensive picture of the concept of cultural resistance and its effect on students' activities, learners social, learners culture. Rosala (2016) argued that dance education based on local wisdom could be used as an alternative learning in schools in building the character of the nation, among others are: Producing generations that are competent and dignified; Reflecting cultural values; Participating in shaping the character of the nation; Contributing to the creation of national identity; Participating in preserving the nation's culture.

The nature of learning is the interaction of learners with the learning environment to change behavior and habits. According to Djamarah (2011) learning is an inseparable part of all activities in studying in formal education institutions, individual learning activities to gain a change of behavior and new habits as a whole, as a result of individual experience himself/ herself in interacting with the environment involving cognitive, psychomotor and affective.

Behavior change is one of the outcomes of the learning process. Jazuli (2016) states that learning is a process of interaction between learners and learning resources on a condition that is deliberately created in order to change behavior. Changes in the behavior that is meant concerning changes that occur consciously, continuously, functionally, positive, active and not temporary, have a purpose, the change covers all aspects of behavior. While Sanjaya (2013) mentions that learning requires a strategy that includes considerations relating to the objectives to be achieved, considerations related to materials or learning materials, considerations from the point of view of learners.

Learning involves the cognitive, affective and psychomotor aspects of the learner. Rohmad (2016) explains that cognitive aspects are related to the activities of the mind including the ability to think, understand, remember, apply, analyze, evaluate and create. The psychomotor aspect relates to the orientation of a skill or the ability to respond or act upon learning experience (cognitively and affectively). While affective aspects related to the manner and behavior including character, habits, feelings, intentions, emotions and characters. The results of the learning process affectively appear in the habits and behaviors of learners.

The character is a special characteristic possessed by an object or individual "(Asmani, 2011). While Philips explains that the character is a collection of governance of character that leads to a system, which underlies the thoughts, attitudes, and behaviors displayed (Muslich, 2011). Thomas Lictona explains that character is the nature of a person in responding to a moral situation, manifested in real action through good, honest, responsible, respectful and other good behavior (Muslich, 2011). While Muslich explains character education is the process to shape the character of learners that involves aspects of knowledge (cognitive), feelings, and actions. Education or character formation will not work effectively without these three aspects, and their implementation is systematic and sustainable. Based on those opinions is concluded that character is character, attitudes, behaviors that attached or appear on someone who distinguishes it from others.

Character education is very important to be included in the learning process, one of them through the education of dance. Character education in each 
subject aims to provide moral upbringing, dignity and attitude (Muslich, 2011). According to Damayanti (2014) each subject focuses on the main characters that match the characteristics of the relevant subjects, for example in the arts and culture subjects integrating traditional dance lessons with the character of religiosity, honesty, intelligence, integrity, concern, democracy, respect for diversity, respect for others' works, curiosity and discipline. In art lessons in particular also have character. In fact, indirectly art can develop basic skills such as physical, percy, piker, emotion, inventiveness, aesthetics, and also can develop child talent (Pekerti, 2007).

Dance education is a strategic entry point for applying the development of character establishment of learners through experiences that result in students' involvement in appreciating the artwork, revealing the philosophical character, religiosity, passion and message embodied in a work of art. Jazuli (2016) explains that appreciating, performing and creating an art dance in it there is a link between the concept of form, creativity, taste, intention and work.

Performing arts including dance lessons performed in schools are basically not to make children as artists or professional dancers, but to encourage the development of creativity, expression, skill and art appreciation, especially traditional dance. Dance as performing art requires deep observation rather than entertainment. Performances as a spectacle art can be divided into show and performing art, dance as show accentuated the physical form of motion and simple composition, luxurious costumes, and beautiful dancers. While performing art prioritizes the artistic character in the sense of prioritizing the weight of the character of the art than the goal, namely the quality, the mature concept and not merely pleasing the audience.

The main performing arts of dance art require some supporting elements in its implementation. Jazuli (2014) explains that performing arts are a spectacle of art which way of appearance is supported by the necessary equipment, valid for a certain period of time. To perform which means to carry out or execute an action or process and there are people who both show and watch. The art of dance performances includes three types, namely traditional dance, creations and modern. Some of the elements that exist in the art of dance are themes, gestures, expressions, and floor patterns (Maryono, 2015).

The theme in the dance is the storyline that can lead a person to understand the essence of dance. The theme can be based on an event or story, which is further translated into a storyline as a draft of a dance. In other words, the theme in dance has an important meaning depicted through its characters and is supported by an expert cast (dancer) in a dance performance. Maryono (2015) mentions the types of themes that generally develop in life such as themes of heroism, loyalty, unity, togetherness, mutual cooperation, harmony, and happiness. One example is a royal story that is usually themed romance and heroism. Traditional dance in Indonesia is usually based on Ramayana stories, Mahabharata, Babat, myth, legend, and history.

Gestures are a means to describe intentions and feelings through non-verbal communication. According to Jazuli (2016), the motion is viewed from strength (power use) or motion impulse that includes intensity, accent or pressure, and quality. Intensity is the power or force used in motion. Accent or pressure is the point of a movement that occurs due to the use of power that varies in the motion, meaning that some movements that use little there are also many of use. Motion quality can be distinguished as light or heavy, loose or limited, fast stomping, direct or indirectly toward the end of the movement phrase. There is an expression factor in all motions, because it is done in order to express the taste, the desire and the mind (Widyastutieningrum, 2014). The motion of expression and expression of motion concerns the psychological factors that are an anatomical body. 
Polatan or expression is the expression of something from a human person such as a raging act to describe anger, hugging to portray a person in love. Expression as an expression using analog as a comparator as well as to explain terms in dance. Wahyudiyanto (2009) argues that expression is the creative process of artists in realizing the idea of an imaginary esthetic form that is coupled with a complex sense of insane into the form of body art and companion media filled with human characters presented in every motion that forms segments motion. The segments of the motion are forwarded to the motion phrases arranged in a structured composition taking into account the dramatic design. The rhythmic motion composition that feels in this dramatic structure, it is what is called the expression that appears in dance. This means that dance is actually revealing the thematic ideas in the form of motion that can be perceived by the contemplator or dancer while in the process of dance.

The floor pattern is the lines made and passed by the dancers on stage. The lines can be either straight lines or curved lines which can then be developed into various line shapes on stage, such as zigzag, diagonal, circle, curve (Jazuli, 2016). The floor pattern is the line where a dancer walks across the floor. These lines are imaginary lines that can only be captured with taste sensitivity. Its form is an illusion or shadow that appears to fuse complementary with the direction of body movement. According to Maryono (2015) the floor pattern is one of the elements that contribute significantly to the visual actualization, the floor pattern is a line formed of the dancers' gestures that cross the floor or the show is an imaginary line that can be captured with taste sensitivity. The floor pattern is required both in single or group dance. In group dance and colossal dance, the floor pattern becomes very important in order to move among the dancer's group looks neatly and well, and gives a solid theatrical impression.
The floor pattern basically consists of two types: symmetrical or balanced and asymmetric. The symmetrical and asymmetrical floor pattern is influenced by the number of dancers. Floor pattern will be strong-established or have weakness also not apart from the design formed. Motion design is divided into three kinds, namely 1) bottom design, 2) middle design, 3) top level.

The basic colors in the performing arts have a symbolic meaning that can lead to the understanding of the characters. The colors are black, white, red, yellow and green. White is a color that has a sacred, loyal and accentuated impression associated with the life of nirvana, for the roles of priests, gods, and commanders. The red color gives the impression of bold, aggressive, and dynamic that many destined figures of arrogant kings, giants, young duke or knights, princesses with a dynamic spirit. Yellow color that has the impression of glamour, luxury, majesty, glory and wisdom. For turmeric yellow is a depiction of the magical atmosphere and the right choice for the clothing of the characters involved. The golden yellow color for the role of king, god and priest. The color green has the impression of fresh, young, grow and live. The color of the green dress in dance performances is widely used for the role of princesses, Gambyong dance, Golek dance, and children dance.

Based on the description, traditional dance learning is supposedly able to meet the social needs of the community and education that can strengthen the character of learners as future generations by bringing the dignity and local wisdom through cultural preservation. In this stu$\mathrm{dy}$, researchers are interested in discussing the learning of traditional dance with its relation in the establishment of the character of learners. This study aims to describe the establishment of learners' character through the learning of traditional dance "Bajul Mahambara" in terms of the learning process, exercises and elements of traditional dance. 


\section{METHOD}

This research is qualitative research. Creswell mentions that qualitative research is a holistic approach that encompasses discovery and description as a development model that occurs in a natural state that allows researchers to develop the detail of self-engagement in a real condition. One feature of the qualitative research is the social phenomenon investigated from the point of view of the actual doer which is very useful for the purpose of describing, explaining, and interpreting the collected data.

A case study approach is used in this study. In this case study the researchers explored in depth a program, events, activities, processes of a person or more. Case studies are either single case or cases tied to the time and place, Creswell (2003).

This research is aimed to understand the learning of traditional dance of Bajul Mahambara as a dance model in SMA Negeri 1 Sragen located in Central Java, Indonesia and how this learning is believed to support the character establishment of learners in SMA N 1 Sragen. The sampling technique used in this research is purposive sampling. Data were collected through observation, interview and literature study. Sources of data in this study obtained from informants, documents and learning process of traditional dance. Informants in this study are principal, deputy head of curriculum, dance teacher, students and parents of learners. The document is in the form of documents on the learning of dance including recording/ note. The triangulation method was used to validate the collected data. This research uses data analysis of Interwoven model, wherein analyzing data, it relates to the relation flowing from three main components that are data reduction, data presentation, and conclusion withdrawal with verification, and data collection process in the field. The analysis process with the three components of the analysis happens when the activity occurs interwoven in the form of a flow of activity flow compile each component of its analysis, and conducts continuously in the process of data collection (Sutopo, 2006).

\section{RESULTS AND DISCUSSION}

SMA N 1 Sragen has applied Curriculum 2013 (K13) as the national curriculum. Therefore, the objectives of the school are formulated based on the national educational objectives that is to build and develop the character and civilized society where learners are expected to be educated by faith and piety to God Almighty, noble, healthy, knowledgeable, capable, creative, independent and become citizens A democratic and responsible country.

To realize the goals of national education in general and the purpose of the school especially where the character and local wisdom is needed, the school develops the traditional dance learning of $\mathrm{Ba}-$ jul Mahambara as a result of local culture. Bajul Mahambara traditional dance is expected to cultivate character and local wisdom in the establishment of the learners' character. Fajarini (2014) states that local wisdom will effectively function as a weapon -not just a heritage- that equip people in responding and answering to the flow of ages. Digging and preserving the various elements of local wisdom, traditions and local institutions, including useful norms and customs, can function effectively in character education, while conducting studies and enrichment with new wisdom.

\section{Learning Traditional Dance at SMA N 1 Sragen}

Dance in the subject of art and culture in SMA N 1 Sragen which is one of the materials presented to the students. Each subject is developed based on school curriculum guidance. The process of learning to teach dance is done through two main steps: planning and learning activities. One of the materials in dance that is important to teach is traditional dance. Traditional dance is also known as the Nusantara dance. Learning traditional dance in SMA N 1 Sragen is designed to bring the 
characters and local wisdom in the character establishment of learners. To be able to shape the character of learners, traditional dance instructors are required to prepare syllabus and Learning Program Plan (RPP) in accordance with traditional dance learning objectives.

Learning activities should prepare RPP and syllabus as a guide in conducting learning activities. With RPP guidelines, it will deliver the objectives of the learning that we deliver to the learners will be achieved "(interview with Siswantini, January 2017). In addition, the syllabus developed into the indicator is accustomed to the material that will be provided by the educator in the material that will be given "(Interview with Teguh Pramono, January 2017).

RPP is developed based on a syllabus that generally consists of learning objectives, basic competencies, indicators, learning materials, learning methods, instructional media, material resources, learning scenarios and characterization. Table 1 summarizes the basic competencies, materials, methods and models of traditional dance lessons for class $\mathrm{X}$ and $\mathrm{XI}$ in SMA N 1 Sragen.

Table 1. Traditional Dance Learning in SMA N 1 Sragen

\begin{tabular}{|c|c|}
\hline $\begin{array}{l}\text { Learning As- } \\
\text { pect }\end{array}$ & Description \\
\hline $\begin{array}{l}\text { Core Compen- } \\
\text { tence dan Basic } \\
\text { Competence }\end{array}$ & $\begin{array}{l}\text { KI } 1 \text { and 2, and also KD } 3 \\
\text { and } 4 \text { Concept, technique, } \\
\text { Traditional dance motion }\end{array}$ \\
\hline Material & $\begin{array}{l}\text { Basic movement of tradi- } \\
\text { tional dance (Bajul Ma- } \\
\text { hambara dance) }\end{array}$ \\
\hline $\begin{array}{l}\text { Method, Me- } \\
\text { dia, Learning } \\
\text { Model }\end{array}$ & $\begin{array}{l}\text { Presenting, discussing, } \\
\text { drilling, discussing, giving } \\
\text { a task, question and an- } \\
\text { swer, video of traditional } \\
\text { dance Bajul Mahambara, } \\
\text { discovery learning dan } \\
\text { project-based learning. }\end{array}$ \\
\hline
\end{tabular}

Table 1 shows the aspects of learning that are concerned such as media, methods, and learning models used. These competencies are KI-1 and KI-2 in the learning objectives as stated in the curriculum, in the form of competencies consisting of (1) spiritual attitude competence, (2) social attitude competence, (3) knowledge competence, and (4) skill competence. The formulation of the competence of spiritual attitudes, "comprehending and practicing the religious teachings which are embraced"; competence of social attitudes, "comprehending and practicing honest, discipline, responsible, caring (mutual assistance, cooperative, tolerant, peaceful), courteous, responsive and proactive behavior and showing attitude as part of the solution to problems in interacting effectively with the social and natural environment as well as in putting themselves as a reflection of the nation in the association of the world", achieved through indirect teaching, namely paragon, habituation, and school culture, taking into account not only the characteristics of subjects but also the needs and conditions of learners. Meanwhile, the growth and development of attitude competence is done throughout the learning process, and is used as the basis for teachers in growing and developing the character of the students further.

\section{Dance Learning Material Tradition estab- lishing Character}

The material in dance learning includes knowledge and skills given to learners on activities undertaken in order to achieve the goal of creative dance learning. Lesson material presented to learners is associated with cognitive structure in the form of facts, concepts, events, experiences with meaningful learning and memorization. Learning means a process of studying with new information and learning to memorize a process of receiving and mastering the materials provided by the educator.

The subject matter of the skill / psychomotor through the movement of dance, with expressiveness with the movement, space, time, dance structure is form and style, dance activity with creative through creative processing (thinking, logic), taste (emotion, aesthetic), intention 
(determination and ethics), work processing (kinesthetic, physical fitness, dance demonstration), dance activities with appreciation can be achieved if learners are able to become doers of aesthetic quality and choreography (Jazuli, 2016).

In the art of dance, the motion is the greatest supporting element of its role in the dance. With the motion can occur the change of place, the change of position of the object, the body of the dancer or part of the body. All motion involves space and time. In space something moves in a certain distance, and the distance within a certain time is determined by the speed of motion. In dance all the motion requires power from the dancer itself, Djelantik (2001). The basic elements of dance are motion, space and time, Astini (2007). Motion can be interpreted as gestures, eye movements, hands and footwork. Space involves body space such as agem motion and its composition, called internal space, while external space includes the stage and floor of the venue. Time is related to the duration of the movement, the short length of the dance and the musical rhythm. From the description above, can be concluded that the art of dance is the expression of the characters of beauty and the whole through the motion of the whole body, space and time in accordance with the rhythm, symbols, characters, themes and goals of the dance. The material is the dance movement of Bajul Mahambara tradition.

Bajul Mahambara Dance is a type of traditional dance with the fighting theme. It seems visible in footwork, body, hands and heads which are handsome and firm (Figure 1).

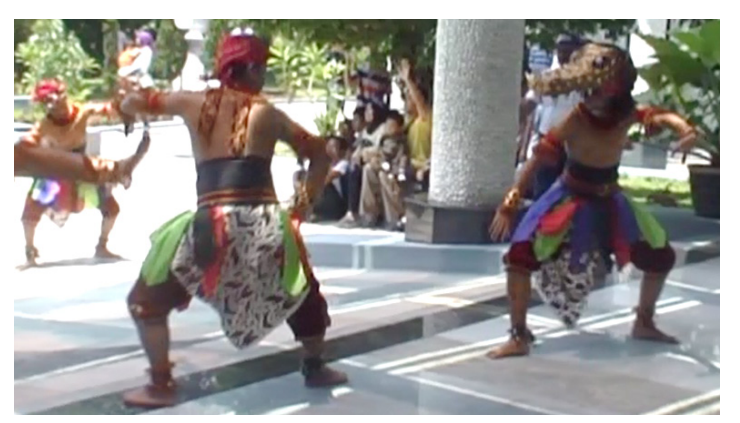

Figure 1. Tari Bajul Mahambara
Trailers from the dance are:

«I ..... Bajul Mahambara ..... Even though I am manifested as an animal, but my sacrifice and my loyalty exceed human nature for the sake of the state, for the sake of the nation, and for the sake of my motherland I stand as a fortress of my country, not a piece of land I give to anyone. Rawe rawe rantas malang malang putung... I ...... Bajul Mahambara ......

Bajul Mahambara dance was created on 22-27 February 2012 by art team of Sragen regency (led by $\mathrm{Mr}$. Jonet) under the supervision of the Cultural Tourism Office of Youth and Sports of Sragen Regency with the activities of Traditional Dance Arts Training Area located at Sangiran Tourism Object of Sragen Regency in collaboration with Culture and Tourism Office of Central Java Province. With training activities create a new art form that can be used as identity and icon of Sragen regency.

Learning material of dance tradition in Bajul Mahambara dance is basic motion consisting of head movement, body, hands, and feet. Bajul Mahambara dance with basic motion of head movement among others motion gedeg/ pacak gulu, nyledet, toleh kanan, toleh kiri, angguk, nggeliyer, nggambul, body movement such as hoyog, engky$e k$, polatan, oklak, entrag, hand gestures such as ngithing, ukel, ngrayung, tawing, mboyo mangap, ngrayung, seblak sampur, ngepel, bapang, kambeng, tumpang tali, sembah, selut, tepak bahu, foot movement diantarnya silo, jengkeng, jinjit, gedrug, jengkeng, debeg gejug, lumaksana, enjeran, ngrodha, mendhak, srisig. Bajul Mahambara dance movement has typical elements in dance, the element of space related to the level setting. Time element associated with the tempo and energy associated with the power of motion dance pressure of Bajul Mahambara, so that learners can perform Bajul Mahambara dance.

\section{Methods, Media, Dance Learning Model for Shaping the Character of Learners.}

Learning method is a way to perform or present, describe, give examples, and provide training content of the lesson 
to learners to achieve learning objectives, Agib (2014). The learning method for dance learning is standard for dance learning process because with the learning method, the educators will be easier to convey material related to techniques in dance. Learning methods used in dance learning include lecture method, demonstration, question and answer, appearance, discussion, and practice with friends.

"Lecture method" is a method in the form of explanation of concepts, principles and facts, learners will establish discipline and responsible character. "Demonstration method", is a method undertaken to demonstrate to learners. This method in the dance learning of Bajul Mahambara is very dominant because the learning is equipped with practice, learners practice that is exemplified by educators, how the process of movement of the dance, learners participate actively in experimenting with the learning process, so that it will lead to establish discipline character and responsible in the exercise. "Question and answer method", the right method for dance learning, learners more focused on educators with direct question and answer. "The method of appearance", the method is in the form of implementation of practice appearance with the guidance of educators. In the dance lesson, to give sufficient explanation to the learners who practice dance by doing guidance, also become remedial learners. "Discussion method", in learning dance method of discussion used the interaction between learners with learners, while educators will analyze, solve problems, explore, debate topics and issues, guide learners in appreciating the opinions of others. "Method of training with friends", this method is used to help learners who are less able to learn dance, then a friend can act as a coach, a mentor.

The media used in traditional dance lessons is the Bajul Mahambara dance video. The making of the video has been done by recording the dance accompaniment of Bajul Mahambara which takes time, energy, thoughts in combining the dance moves into a video dance of Bajul
Mahambara. In the process of making the video, it requires the character responsibility, discipline, creative, tolerance. With the character established in making video dance Bajul Mahambara, the learners understand that the process of making a dance video is difficult and requires responsibility and discipline.

The selection of appropriate learning model is adapted to the characteristics of learning, research object using Curriculum 2013, developed learning model that can encourage and motivate learners in developing ideas and creativity, so that learning is more interactive, fun, and inspirational, that encourage learners to participate actively in the discussion as well as activities that can improve self-confidence. According to Widodo, Kristiani, and Mulyana (2016), things can be considered in determining the learning model to be used as follows: (1) the suitability of the learning model with the characteristics of the subject, (2) the suitability of KD-KI 2 characteristics that can develop the competence of attitudes, and the appropriateness of learning materials with the demands of KD-KI 3 and / or KD-KI 4 to develop knowledge and skills competencies; (3) the suitability of learning models with specific learning objectives in developing potential and competence, for example to develop social interaction, or processing information, (4) the use of learning model with scientific approach.

Learning model that is relevant to the characteristics of traditional dance art of Bajul Mahambara is the model of Discovery Learning (DL) and Project Based Learning (PjBL). The learning model of Discovery Learning emphasizes the finding of previously unknown concept or principle (Kemdikbud, 2014). Problems faced by students are some kind of problem engineered by educators. Stimulation Stage, the learners observe Bajul Mahambara dance videos aired by educators to cultivate the character of responsibility in doing the task. Meanwhile, the problem statement of learners is in the form of Bajul Mahambara dance video show about the concept, 
a technique so as to build the character of cooperation and responsibility.

Data collection identifies the concept of Bajul Mahambara dance where the learners are creative in digging information. At the stage of "data processing", learners create a schedule of practice with mutual cooperation and responsibility. In the "verification" stage, the learners conduct discussion. This task cultivates a sense of creativity, responsibility, cooperation, discipline, and honesty. The "generalization" stage, the learners present Bajul Mahambara dance in order to build cooperation, honesty, responsibility, and creativity. Project Based Learning (PjBL) learning model is a learning model that uses the project as the core of learning.

The stage of "design a plan for the project", is to form students in groups to make pattern of floor and dance level of Bajul Mahambara dance with responsibility, cooperation, creativity, and the progress of project learners practicing the pattern of dance floor Bajul Mahambara with monitoring the student responsibility, discipline, cooperation, tolerance. The stage of "asses the outcome", learners present the characterization Bajul Mahambara dance with discipline, responsible, cooperation, tolerance. The stage "evaluate the experience", learners receive an evaluation of Bajul Mahambara dance brought with responsibility and discipline. With the learning model, learners have established the character of discipline, honesty, responsibility, creativity, tolerance so that learners can perform Bajul Mahambara dance.

\section{Character Education through Traditional Dance Learning}

The experience of traditional dance learning aims to further encourage implicit character establishment. In addition to learning the movement of Bajul Mahambara dance and the floor pattern by practicing it, learners also learn traditional dance in Indonesia including the story behind the dance, the variety of motion and the meaning. Learners also automatically learn about the characters and local wis- dom contained in the traditional dance art when learners try to understand the history and meaning of every move because of the traditional dance produced by the society especially in Baju Mahambara dance.

Bajul Mahambara dance is chosen because it is a product of civilization in the form of cultural expression and art, the characters and local wisdom is implicitly represented in these dances.

\section{Religious}

The learning of traditional dance influences the establishment of learners' character that is religious, Amriullah (2013), says that religious is a behavioral attitude that obedient in implementing the religious teachings it embraces. Traditional dance in Indonesia implicitly contains the religious characters brought by the creator. Traditional dance is one form of folklore delivered through motion symbols. Some movements are meant to illustrate human obedience to God can be found in traditional dance. Folklore or traditional dance depicts the stories of nature, heroism, exemplary that has certain characteristics throughout the territory of Indonesia. Folklore or saga is usually created based on the existence of divinity. Students who present traditional dance must be asked to understand the real meaning of the whole dance and turn the story to give the dish a true dance, so that they are able to convey a message from the story of dance or theme.

Humans in modern society often separate religious characters or their beliefs from the characters in science, or the unbalanced nature of the two, are more concerned with either combining them. This view makes individuals who are not whole, as individuals who are disintegrated, this is the problem of the life of modern society. This is reinforced by Dewey's opinion quoted Ghulam Haider Aasi as "The problem of restoring integration and cooperative between man's beliefs about the world in which he lives and his beliefs about the values and conditions that should direct his conduct is the deepest problem of modern life (Ghulam, 1985). 
In the learning of Bajul Mahambara dance art, religious character is instilled in several ways. the first is the planting of religious character through the learning process. The second way is done through the training process. While the third way is done by inculcating the elements of Bajul Mahambara dance. The characteristic diversity of dance art that is grown in the belief of learners as a gift of God Almighty that the human work there will be no intervention of God. In addition to this as a form of practice to the art of dance learners can find the theme of the dance is the theme of animals, nature, as the basic idea of God's greatness that of the theme that can be a manifestation of God's grace. The series of work processes, learners in groups can show the results of the modification of the floor pattern of Bajul Mahambara dance. In the educational process explains that the effort is a gift from God that should be grateful. The experience of learning to work in dance fosters learners to give thanks for God's gifts. At the time of learning educators always greeting before and after learning.

Exercise is a way that learners do in the process of creating dance creations. Exercise activities always begin by praying together. This activity is the cultivation of character to learners to always remember to God when beginning and ending in practice. The activity will become a habit of learners that reflect the religious character. In the elements of dance elements, religious characters are found in various dances, namely the basic motion of dance, for example the variety of motion of the lord begins with the standing position with the slanting upward right foot poses, the foresight. The process of jengkeng, after jengkeng both hands (palms) put together (nyembah), head shook to the right and to the left according to the count. The motion also teaches that humans are smaller creatures larger than the Great One, thus teaching also that humans must humble themselves (jengkeng) first, by asking for protection from Allah SWT. With a low level (jeng$k e n g)$ it is the actualization of the religious character contained in the range of motion. Spirituality or religion is not just a metaphysical understanding of reality or a series of dogmatic and ethical attitudes; it is also a physical exercise. A religious phenomenologist who recognizes this is Leeuw (1963), who studies such phenomena that appear as dances and religions simultaneously. LaMothe (2004), who builds on Van Der Leeuw, argues that dance should be included in religious studies. This seems to be a relevant perspective in understanding the religious life of dancers who participate in this research project and dancing in Christian settings, for whom dance is an important part of their spiritual practice. It has also been investigated by Schuff (2012) regarding dancing to personal and spiritual growth.

\section{Honesty}

In traditional dance learning, honesty appears in imitative activity when learners observe and simulate dance observed as a reference and consciously understand that the movements are the creations of others. Next they have to explore their own ideas to create their own floor pattern. Learners should understand how to appreciate the work of others, develop, explore and modify independently in creating their own creations. Because the dancing itself has actually taught the character of honesty directly to the community because dancing is a skill that can be seen directly in a show.

Educators teach that in imitating the dance of local traditions (archipelago) according to the accompaniment and work of dance to work in accordance with its ability. The honesty done by the learner can create a description of dance with theme and synopsis with honest attitude, make description according to reality and submit the result of report accompanied with the observation of dance presentation. The art of dance teaches to always be honest because dancing is a skill that can be seen directly that learners can perform dance moves. Can or can not do, it must be said honestly.

The character of honesty can also be 
seen in elements or elements of Bajul Mahambara dance which can be seen on the dance property. Learners use the red, yellow, green, white properties are the colors in the white property symbolize the character of honesty or sanctity. The element of facial expression/ polatan means the expression in showing honesty in dancing. The facial expression in the play is a form of honesty from within the dancer being shown to the audience.

Based on the planting of positive characters by educators then the art of dance lessons to contribute to the formation of the character of the learners is the character of honesty. This is also in line with the statement of Costa (2016) in his research that the circle dance appears to facilitate the trust between people, based on qualities such as honesty and openness that penetrate the social world of the dance circle. According to Kohlberg (Hurlock, 2002), the child's morality is seen when he follows the rules and can take the hearts of others, and can maintain good relationships. Related to that, the moral character that can be observed from the learning of dance art Bajul Mahambara is the stimulation of the character of obedience and the character of a child's honesty.

\section{Responsible and Cooperation}

Responsibility is a person's attitude in performing tasks related to himself, the environment, society and beliefs. The character of responsibility is depicted in the dance elements of motion and the formation/ floor pattern. This movement forms responsible characters. The motion in dance is the expression of the soul of the dancer through the body motion. Learners are required to display every movement in the dance correctly based on wiraga (rules of motion), wirama (music or rhythm) and wirasa (characters).

In that case, the floor pattern or the formation allows the learners experience to form the formation by moving the position of the dancers in the group. Learners can be shaped responsible characters in their respective parts because if one per- son made a mistake on his part can cause chaos group formation. As stated by Nurharini (2003) that the learning of dance is able to cause the confidence of children in the form of the growing feeling of pride, have the character of brave, able to control emotions, cultivate sense of responsibility and self-reliance, easy to interact with others, have better achievement, develop his imagination and creativity.

The character of responsibility was developed in the learning by educators in the attitude and behavior of learners to perform tasks both tasks for educators and tasks with friends of his group. At the end of each learning, the educator gives the tasks to do at home related to the dance that has been learned to be memorized that is the traditional dance of Bajul Mahambara and the learners memorize the exploration of dance movement from the basic motion of dance. The character of responsibility has been applied by educators with the intention of how learners have responsibility for their duties.

The traditional dance of Bajul Mahambara or folklore tells a story which means most traditional dances are performed in groups. The dance lessons are done in groups in performing project tasks to present a dance. Thus, learners are given the experience to work together in teams to discuss and display the dance. Each group of learners with diverse abilities help each other and support each other in learning, exploring, understanding, creating their own dance which is formed based on the elements of motion, rhythm, appreciation of characters and ultimately present a dance creation. According to Vygotsky in his theory, he emphasizes the interaction between the "internal" and "external" aspects of learning and its emphasis on the social environment of learning Schunk (2012). The theory of Vygotsky, cognitive function derives from the social interaction of each individual in the concept of culture.

\section{Tolerance and Benefits}

Tolerance according to Nasir (2013) is the attitude and action that respects dif- 
ferent religious, tribe, ethnic, opinion, attitude, and other people's different from him. Bajul Mahambara traditional dance contains the character of tolerance as well as courtesy. This is evidenced by the existence of traditional dance Bajul Mahambara that serves to welcome guests. This means that our society is an open society and respectful of guests.

Bajul Mahambara traditional dance that has a characteristic in every movement that is a motion like a crocodile. The learning of traditional dance Bajul Mahambara gives a picture to the learners about the differences. Each tribe has its own way of expressing something through motion and rhythm though it conveys the same intention. At this point, learners are implicitly encouraged to take lessons from each dance and accidentally put personal tendencies towards a dance. Learners are trained to be objective in appreciating dance even though it is not included in his taste.

The tolerance character is depicted in the formation element / floor pattern. Dancing with the correct formation shows the character of a dancer's tie tolerance to other dancers in a team. Dancers should be able to match the taste of each other so as to convey the message of dance in its holistic. They must be able to read the situation to achieve conformity within the team. Tolerance is also seen when learners do exercises in dance and give mutual input for each member so there is no seniority or who feels smarter, in this case mutual tolerance in performing dance movements are created.

In addition to this attitude, tolerance is also seen when learners get an evaluation or input from friends, tolerance here built through mutual respect for friends. Learners in the work of dance groups meet different dissentions and frequently make mistakes. Therefore, learners appreciate the difference between the opinion of a group of friends. This is agreed by Rosala (2017) who states that the cultivation of moral character of tolerance in students through dance learning is mutual respect for the opinions of others by one way dia- logue through creative dance.

Through learning the dance is also obtained knowledge of manners which are all unwritten rules that have been given by educators with the meaning that the rules are running in the class so as to cause a sense of courtesy. For example, in learning to express an opinion by saying courteously and did not say harsh words to his friend during practice, the students were courteous by kissing the teacher's hand before entering the class, greeting the friend when meeting his friend, the example of courtesy gained from learners when observing video dance Bajul Mahambara as media at the beginning of the dance to give respect and activities that have aesthetic characteristics which do not leave the attitude of politeness. In addition, tolerance can be cultivated by respecting the appearance of other groups and giving a good appreciation in a polite way. Courteous behavior can arise if students are involved in a relationship. According to Tomayahu (2014) polite behavior is a regulation of life that arises from the result of the association of a group of people in society and is regarded as the daily social guidance.

\section{Discipline}

Syarbini (2013) discipline is an act that shows orderly conduct and obeys the various rules and regulations. Learning traditional dance art Bajul Mahambara here reminds learners to discipline in time, effort and patience. Learners not only learn the theory but also practice dance along with its elements because learners are eventually asked to perform the dances they have learned. Discipline is also reflected in the rules of dance classes such as time management where learners need to prepare their own including costumes and equipment. In the opinion of dance art educator Siswantini said that: "Learners in following the dance learning should have discipline which is discipline in following the lesson, discipline in their dance practice and if doing exercise in the practice room also have to use time well, because classroom with practice room was 
moved for not wasting learning time" (Interview, January 2017).

Motion and formation is a dance element that demands the discipline of the dancers who are the learners themselves. Variety of motion must be done in accordance with the accompaniment or rhythm (wirama). The accuracy of motion and accompaniment means dancing with tempo. Continuous training implicitly fosters the discipline of learners. This is in line with the results of research conducted by Kamtini (Fitrianti \& Reza, 2013) that the learning of motion and a creative song is a singing activity while moving in accordance with the rhythm of music and songs by doing learning innovation to improve hard motoric, increase creativity, learn to socialize and cooperate, train discipline, and train children's concentration.

\section{Creative}

Muchlas (2012), says that creative is thinking and doing something to produce a new way or something. Bajul Hambara dance lessons encourage learners to practice practically their creativity through practice, appreciation, exploration and creating dance work in groups. Improving the range of basic motions provides students with the experience to engage in a creative process in which the improvisation leads them to produce their own dance creations. Triana (2015) states that an artist, in this case a choreographer, conveys his expression through a rhythmic and beautiful movement, both stylized and distorted as the ability to think creatively to explore the idea into a dance creation. Creativity according to Rhodes (1961), distinguished into the dimensions of the person, product process and press, while the creativity itself according to Supriadi is a person's ability to produce something new, in the form of ideas and works that are relatively different from what has been there before. Similarly, creativity according to Munandar, is the ability to create new combinations based on data, information or elements that exist (Munandar, 1987).
The creative process of the learner can also be done with a regular exercise. Through dance group exercises can create patterns of the dance floor, a creative attitude which is always active to make the arrangement of motion is more optimal. Creative character through the process of exercise is in elements of dance elements of motion and accompaniment or music. Variations of floor patterns and dance movements are a reflection of creative attitudes in the range of free motion in the order of dance, the basic motion explored is a form of improvisation of creative movement of each dancer (Figure 2). Arrangement work of dance gives space to the dancers to think creatively in accordance with their own desires by still accompanied by music. Creative music is also shown by accompaniment by improvising the dancer's movements. The accompaniment here must be good at adjusting the rhythm of the dancers' movement, this is to keep the wirasa of the dance that is danced and to strengthen the wiraga and wirasa in dance creations developed.

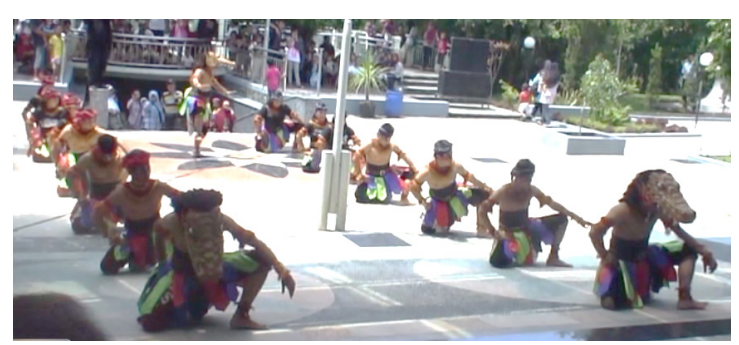

Figure 2. Example of Floor pattern of Bajul Mahambara dance

Creativity process conducted by learners in the group have their own characteristics. This can be seen through the different ways each group. The process occurs among learners who influence each other's behavior from the passive becomes more active. Regular exercise provides a continuous process for forming optimal motion and formation. Variety of motion and accompaniment or music produces an exploration space in the learners to perform Bajul Mahambara dance movements with the right tempo and rhythm, in addition to motion exploration with 
themes. Beetlestone (1998) sees creativity and art as closely related through the thread of representation (self-expression of ideas and feelings, such as through expressive art). He stressed that children should be able to take ownership of processes as well as products to be motivated. Thus, it is seen that every aspect of the character is closely related to the aspects of learning. More concretely the relation of the character form to the influencing aspects of learning can be presented in Table 2.

Table 2. Characters in Learning Traditional Dance

\begin{tabular}{cc}
\hline Character Name & Learning Aspect \\
\hline Religious & Concept, material \\
Honesty & Method, material \\
Responsibility dan & Media, method, mate- \\
Cooperation & rial \\
Tolerance & Media, material \\
Discipline & Media, learning \\
& model,method, mate- \\
& rial \\
Creative & Media, learning \\
& model, material \\
\hline
\end{tabular}

\section{CONCLUSION}

Character building is very important in education because one of the goals of education is to provide care for learners. The establishment of this character is achieved through the process of dance learning which includes messages of meaning in the dance, learning process, and the behavior or achievement of learning.

The traditional dance lessons of Bajul Mahambara dance give the learners experience to form the character positively as (1) to grow the religious character through dance practice, (2) to develop the character of honesty through the students' appreciation activities, (3) to encourage the sense of responsibility and cooperation by understanding the elements dance like floor patterns, (4) acquire tolerant and corteous character trained through appreciation activities, (5) train the discipline of learners through demands and rules to learn traditional dance, and (6) encourage creativity that occurs when learners try to understand the elements of dance and modify it.

The learning of traditional dance of Bajul Mahambara is the right way to give learners experience about the characters and local wisdom so that they grow into a nationalist personality.

\section{REFERENCES}

Aasi, G. H. (1985). Dewey and Iqbal on Moral Self and Society: A Comparative Study of Their Thought. Hamdard Islamicus, 8(1), 51-63.

Amirullah, S. (2014). Model Pendidikan Karakter Dalam Keluarga. Jakarta: Gramedia

Asmani, M. (2011). Pendidikan Karakter. Jakarta: Bumi Angkasa.

Beetlestone, F. (1998). Creative children, imaginative teaching. Buckingham: Open University Press.

Borges da Costa, A. L., \& Cox, D. L. (2016). The experience of meaning in circle dance. Journal of Occupational Science, 23(2), 196-207.

Damayanti. (2014). Panduan Implementasi Pendidikan Karakter di Sekolah. Yogyakarta: Araska.

Djamarah, S. B. (2011). Psikologi Belajar. Jakarta: PT. Rineka Cipta.

Creswell J. W. (2003). Research design: qualitative, quantitative and mix method approaches. London: Sage Publication

Fajarini, U. (2014). Peranan kearifan lokal dalam pendidikan karakter. SosioDidaktika: Social Science Education Journal, 1(2), 123-130.

Fitrianti, D., \& Reza, M. (2013). Mengembangkan Kegiatan Gerak Dan Lagu Untuk Meningkatkan Kemampuan Motorik Kasar Pada Anak Usia 5-6 Tahun. PAUD Teratai, 2(3) 1-6.

Hurlock, E. B. (2002). Psikologi Perkembangan: Suatu Pendekatan Sepanjang Rentang Hidup. Jakarta: Erlangga.

Jazuli, M. (2008). Peran Seni Budaya Suplemen Pembelajaran Seni Tari. Semarang: Unnes Press. 
Kemdikbud. (2014). Implementasi Kurikulum 2013 Mapel Seni Budaya. BPSDMP dan Penjaminan Mutu.

LaMothe, K. L. (2004). Between Dancing and Writing. The Practice of Religious Studies. New York: Fordham University Press.

Maryono. (2015). Analisa Tari. Surakarta: ISI Press.

Munandar. (1987). Memupuk Bakat dan Kreativitas Anak Sekolah Menengah: Petunjuk Bagi Guru dan Orang Tua. Jakarta: Gramedia.

Muslich, M. (2014). Pendidikan Karakter. Jakarta: Bumi Aksara.

Nurharini, A. (2003). Pembelajaran Seni Tari sebagai Sarana Pengembangan Rasa Percaya Diri Anak di Taman Kanakkanak Pangudi Luhur Bernadus Semarang. Doctoral dissertation. Art Education of Post Graduate, Universitas Negeri Semarang Tahun.

Pekerti, W. (2007). Pendidikan Seni MusikTari/ Drama. Jakarta: Universitas Terbuka

Rhodes, M. (1961). An analysis of creativity. The Phi Delta Kappan, 42(7), 305310.

Rohmad, Z. (2016). Asesmen dan Evaluasi Pembelajaran. Surakarta: UNS Press.

Rosala, D. (2017). Pembelajaran Seni Budaya Berbasis Kearifan Lokal Dalam Upaya Membangun Pendidikan Karakter Siswa di Sekolah Dasar. Ritme, 2(1), 16-25.
Sanjaya, W. (2013). Strategi Pembelajaran (Berorientasi Standar Proses Pendidikan). Jakarta: Kencana Prenada Media Group.

Schuff, H. M. T. (2012). Dancing towards personal and spiritual growth. Nordic Journal of Dance, 3(1), 30-40.

Schunk, D. H. (2012). Learning theories an educational perspective (sixth edition). Pearson: The University of North Carolina at Greensboro

Suharji. (2015). Tari Gandrungan: Konsep Dasar dan Bentuk Tari Gagah Gaya Surakarta. Surakarta: ISI Press.

Sutopo, H. B. (2006). Metodologi Penelitian Kualitatif. Dasar Teori dan Perapannya dalam Penelitian. Surakarta: Universitas Sebelas Maret.

Triana, D. D. (2015). The Ability of Choreography Creative Thinking on Dance Performance. Harmonia: Journal of Arts Research and Education, 15(2), 119-125.

Trustho. (2005). Kendang Dalam Tradisi Tari Jawa. Surakarta: ISI Press.

Wahyudiyanto. (2009). Wajah Tari Dalam Perspektif. Surakarta: ISI Press.

Winarsih, R. (2014). Pengembangan Pendidikan Karakter melalui Seni Tari klasik gaya Yogyakarta di SMK 1 Kasihan Bantul. Desertation. Universitas Negeri Yogyakarta.

Widyastutienngrum S. R. (2014). Koreografi. Surakarta: ISI Press. 